\title{
The freshwater jellyfish Craspedacusta sowerbii Lankester, 1880 (Limnomedusa: Olindiidae) in Germany, with a brief note on its nomenclature
}

\author{
Gisela B. FRITZ*, Ralph O. SCHILL, Martin PFANNKUCHEN and Franz BRÜMMER \\ Universität Stuttgart, Biologisches Institut, Abteilung Zoologie, Pfaffenwaldring 57, 70569 Stuttgart, Germany \\ *e-mail corresponding author: gisela.fritz@bio.uni-stuttgart.de
}

\begin{abstract}
The freshwater jellyfish Craspedacusta sowerbii Lankester is distributed worldwide in temperate, freshwater habitats. However, such a successful, worldwide dispersion of the medusa and its minute, less obvious polyp is unique among the freshwater jellyfish species (Limnomedusae, Olinidiae). Although numerous reports were given shortly after its discovery, the interest did not cease over the years. In cooperation with the German Underwater Federation (Verband Deutscher Sporttaucher e. V.) additional data of freshwater jellyfish occurrences could be obtained. In combination with previously published discovery reports, these data provide an area-wide observation of the distribution of freshwater jellyfish within the Federal Republic of Germany, adding 21 to the previously known C. sowerbii locations. Indications are that there is a far more wide spread distribution of the medusa than thought and the potentially even wider distribution of the often times overlooked polyp.
\end{abstract}

Key words: Cnidaria, distribution, freshwater jellyfish, neobiota

\section{NOMENCLATURE}

The first descriptions of the freshwater jellyfish were published within a few months after its discovery in a water lily tank in Regent's Park, London, England in 1880 (Allman 1880, Lankester 1880a, Lankester 1880b). The first written report was presented by E. Ray Lankester naming the new medusa Craspedacusta sowerbii (Lankester 1880a). Within a week, J. Allman gave a presentation describing the same species naming it Limnocodium victoria (Allman 1880). A name dispute arouse, which was not eased by the fact that Lankester "in respect to Allman" suggested the name Limnocodium sowerbii (Lankester 1880b). The International Commission on Zoological Nomenclature (ICZN) decided on C. sowerbii, Lankester (Allen 1910, Stiles 1910), as a presentation is not considered to be equivalent to a publication. It is noteworthy to mention that almost $40 \%$ of all viewed literature use "sowerbyi" instead of the correct, as given in the first publication by Lankester, "sowerbii" and about $80 \%$ of those were published after the 1970s.

\section{DISTRIBUTION}

Within a few decades of the discovery of $C$. sowerbii reports and observations from all continents on its distribution were published. Although the jellyfish was considered to be from South-America, it was shown in the 1950s that the species originated from the Yangtsekiang River system, China (Kramp 1950). Of the limited number of freshwater jellyfish species, Craspedacusta species occur almost worldwide (Acker \& Muscat 1976, Pennak 1956), however, the genus Limnocnida seems to dominate the waters of India (Ahmad et al. 1987) and Africa, with the exception of South-Africa (Rayner 1988). Although multiple species of the genus Craspedacusta have been described, so far five species have been recognized (Boulenger \& Flower 1928) (Fig. 1). Although all of these freshwater jellyfish occupy similar habitats, only $C$. sowerbii, its minute polyps (Fig. 2a) and its medusa $(2.5 \mathrm{~cm})$ (Fig. 2b), shows a worldwide distribution (Acker \& Muscat 1976; Payne 1924; Pennak 1956; Rayner 1988). Possible reasons might be the ability for several forms of vegetative reproduction, such as budding a polyp, which stays attached to form a colony and budding a motile frustule which attaches and builds a new polyp (Dejdar 1934; Reisinger 1957) and, in addition, the successful longterm survival and adaptation to new areas without or with limited sexual reproduction and its genetic advantages. Furthermore, the possible ability to survive adverse conditions by producing a durable, chitin covered resting body (Acker \& Muscat 1976; Bouillon \& Boero 2000a) might aid in the successful conquest of different freshwater habitats.

The immediate interest of the discovered Limnomedusa (Hydrozoa, Olindiidae) was great and did not cease over the years. Usually the medusa was discovered by chance or when looking for some other organism of interest. Interestingly enough, it was mainly observed in artificial bodies of water e.g. gravel pits, as gravel and clay pits, garden ponds, reservoirs, aquaria and even wastewater treatment facilities (Augustin et al. 1987; Davis 1955; Schmitt 1939; Tattersall 1933; Thomas 1951), however, there are some records from natural lakes (Deevey \& Brooks 1943; Dexter et al. 1949; Fantham \& Porter 1938) as well as backwaters or slow 


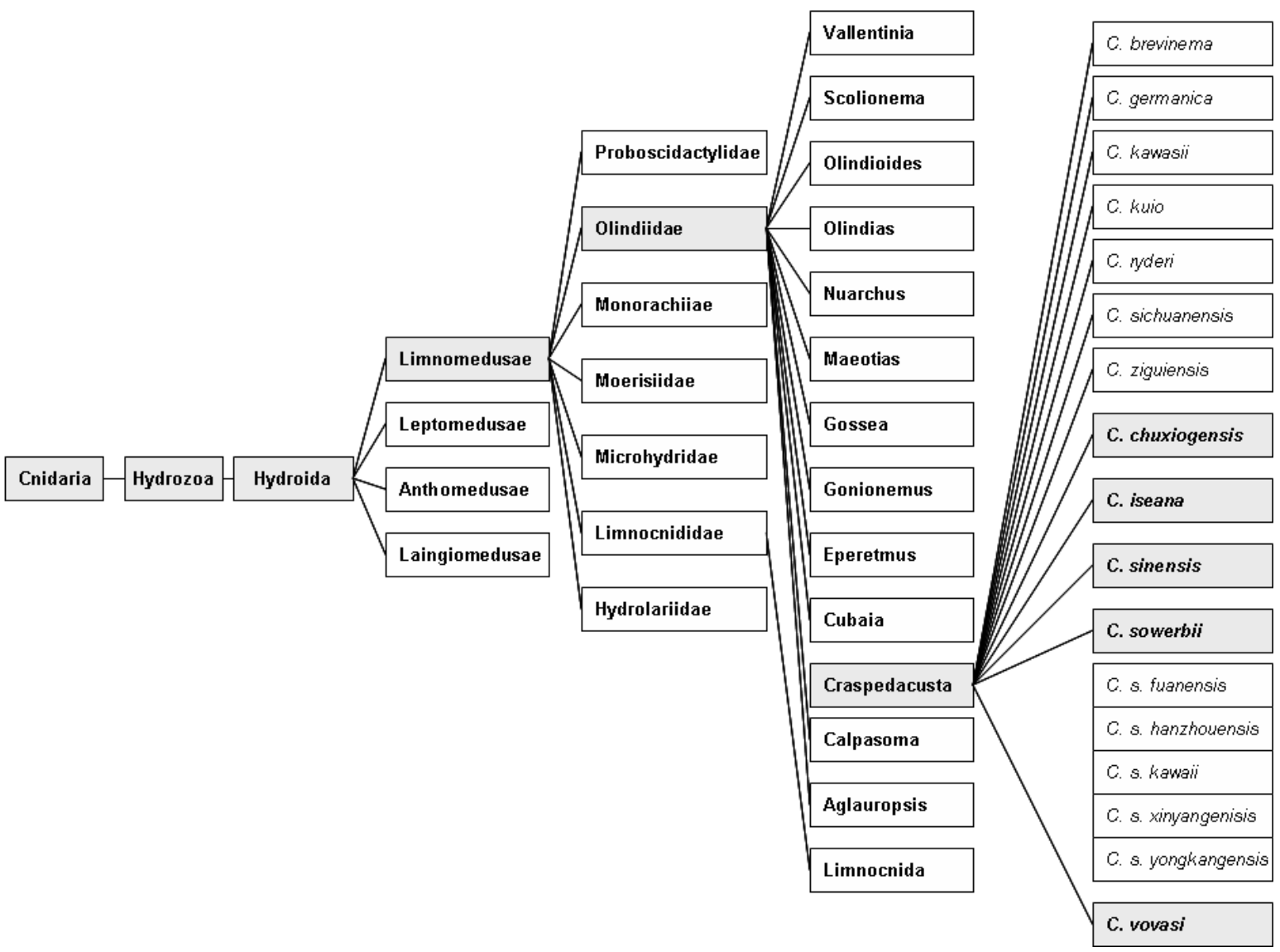

Fig. 1. Phylogeny and Nomenclature of Craspedacusta sowerbii.
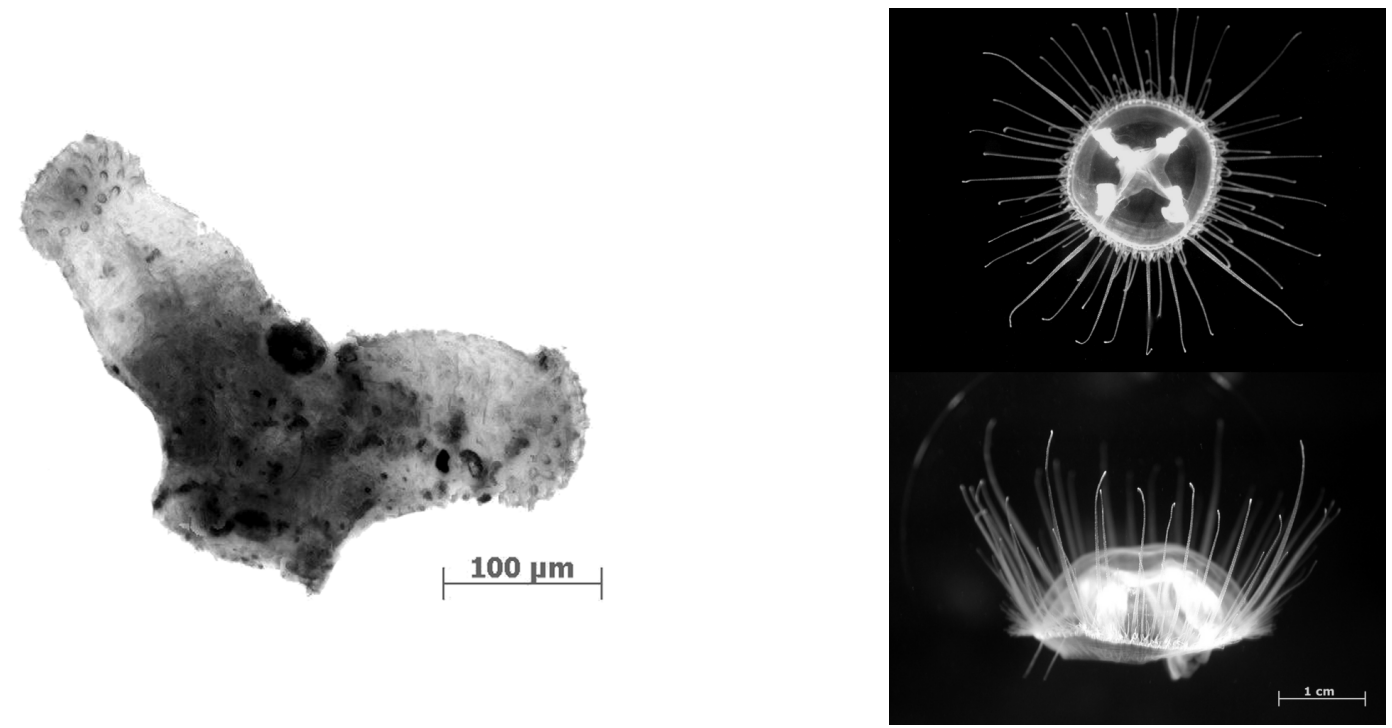

Fig. 2. Craspedacusta sowerbii. Left: a colony with two polyps. Right: two views of the medusa.

flowing portions of streams and rivers (Beckett \& Turanchik 1980; Lundberg \& Svensson 2003; Potts 1897; Rayner \& Appleton 1992). There could be two reasons for that: 1) Non-indigenous plants and animals are more often introduced into artificial lakes than in natural ones and 2) these artificial bodies of water are more closely watched, e.g. for water quality control, biological studies etc., hence chances are greater to observe the medusae (Thomas 1951).

Like in many other countries, several observations were made in Germany in the early 20th century (Fig. 3a). One of the first observations, that also included a 

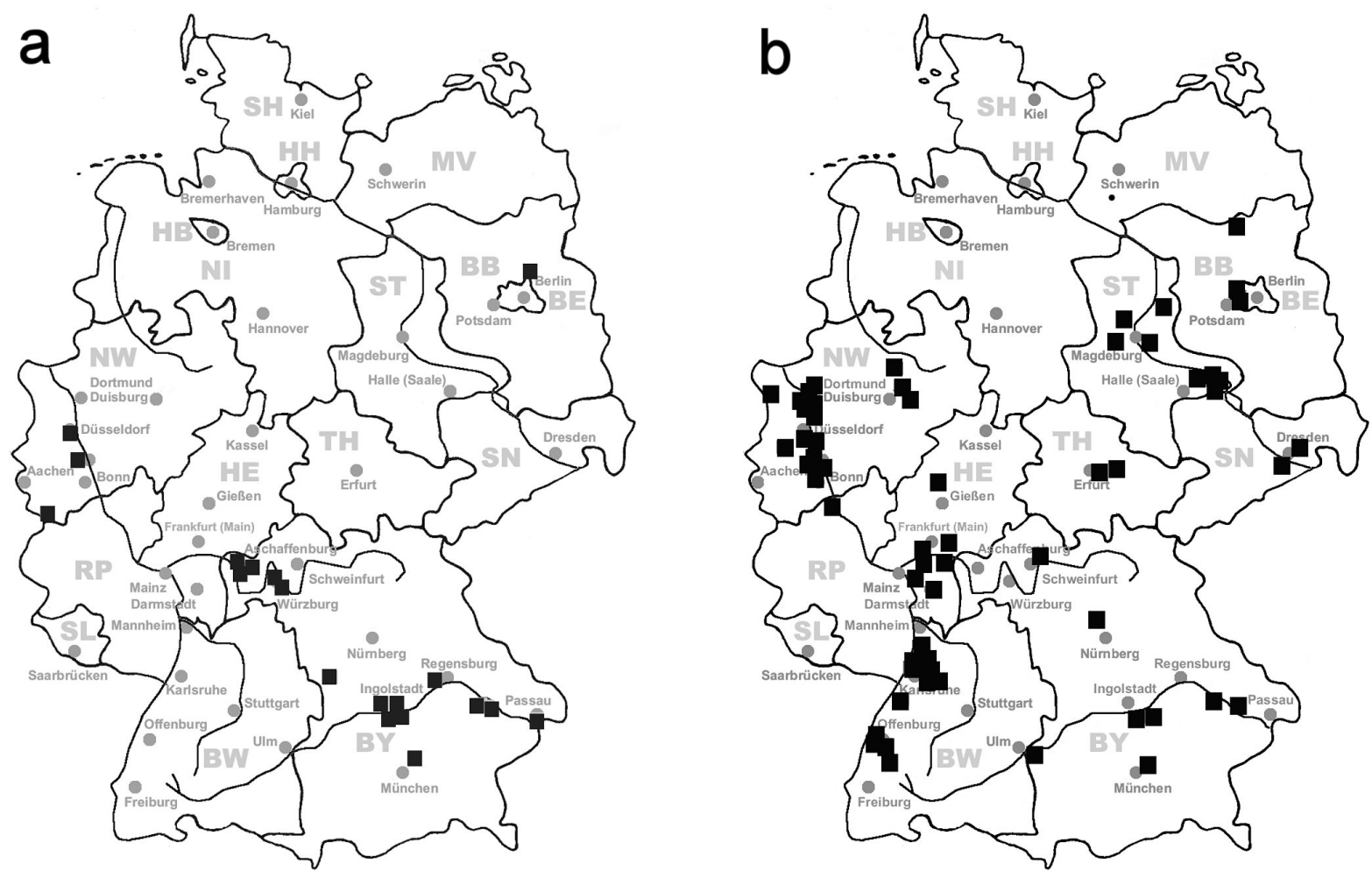

Fig. 3. Reports of Craspedacusta sowerbii in Germany. Reported locations of Craspedacusta sowerbii $\mathbf{a}$ : before 1990 and b: after 1990. Gray dots indicate selected cities within Germany. Capital letters are official abbreviations of the federal states $(\mathrm{BW}=\mathrm{Baden}-$ Wuerttemberg, $\mathrm{BY}=$ Bavaria, $\mathrm{BE}=$ Berlin, $\mathrm{BB}=$ Brandenburg, $\mathrm{HB}=$ Bremen, $\mathrm{HE}=$ Hesse, $\mathrm{HH}=\mathrm{Hamburg}, \mathrm{MV}=\mathrm{Mecklenburg}-$ Western Pomerania, NI = Lower Saxony, NW = North Rhine-Westphalia, RP = Rhineland-Palatinate, SL $=$ Saarland, $\mathrm{SN}=\mathrm{Saxony}$, $\mathrm{ST}=$ Saxony-Anhalt, $\mathrm{TH}=$ Thuringia). Major river systems are shown.

detailed description, reported a medusa found near Berlin which showed several morphological differences to C. sowerbii. Hence, the medusa was published with the name Microhydra germanica (Moser 1930; Persch 1933; Roch 1924a; 1924b), however, later on, several publications showed the similarities of the polyps and the necessity to combine several species, including $M$. germanica and C. ryderi, to C. sowerbii (Bouillon \& Boero 2000a, b; Boulenger \& Flower 1928; Dejdar 1934).

Within the last two decades, an increasing number of reports were made on new Craspedacusta occurrences. This could be due to two main reasons: 1) increasing recreational, aquatic activities lead to an increase in observations and 2) the freshwater jellyfish is spreading. The present study worked in cooperation with the German Underwater Federation (VDST), especially to obtain broad-scale distribution data on the freshwater jellyfish. The data obtained so far (Verband Deutscher Sporttaucher 2006), added 21 additional locations to the previously published information (Tab. 1). The distribution of reports is slightly skewed towards the southwest of Germany (Fig. 3a, Fig. 3b), which is probably due to the availability of appropriate habitat within these areas, with Baden-Wuerttemberg and Bavaria having a lot of artificial bodies of water, whereas the number of lakes in the northeast is lower. The obtained information indicates a far more wide spread distribution of the medusa than thought. Knowing that the minute polyp goes unnoticed in most cases and does not always produce medusae, the polyp probably has a far wider but unknown distribution.

With this ongoing project and further reports on the jellyfish, more research can be done on the distribution of this freshwater cnidarian. Although a lot has been published on $C$. sowerbii, methods of introduction and transportation, numbers of introduction events, as well as details on certain life cycle phases are still uncertain. As for most temperate species, warmer temperatures lead to an increase in production (Purcell 2005), it will be interesting to observe the distribution patterns of $C$. sowerbii in the light of a global warming event. The fact that most Craspedacusta populations are single-sexed (Petrusek et al. 2005), eliminating the evolutionary advantages of sexual reproduction, as well as the fact, that within most countries mainly one sex occurs (Petrusek et al. 2005), gives rise to the hypotheses that there were only a limited number of introduction events to single countries, but a very high mobility within regions to spread from habitat to habitat. Molecular analyses on population level might give more insight into jellyfish dynamics. 
Tab. 1. Distribution of Craspedacusta sowerbii in Germany. Lakes marked with an * have been reported for the first time during this study. Most of the lakes below are artificial bodies of water such as quarry ponds, ponds or gravel pits.

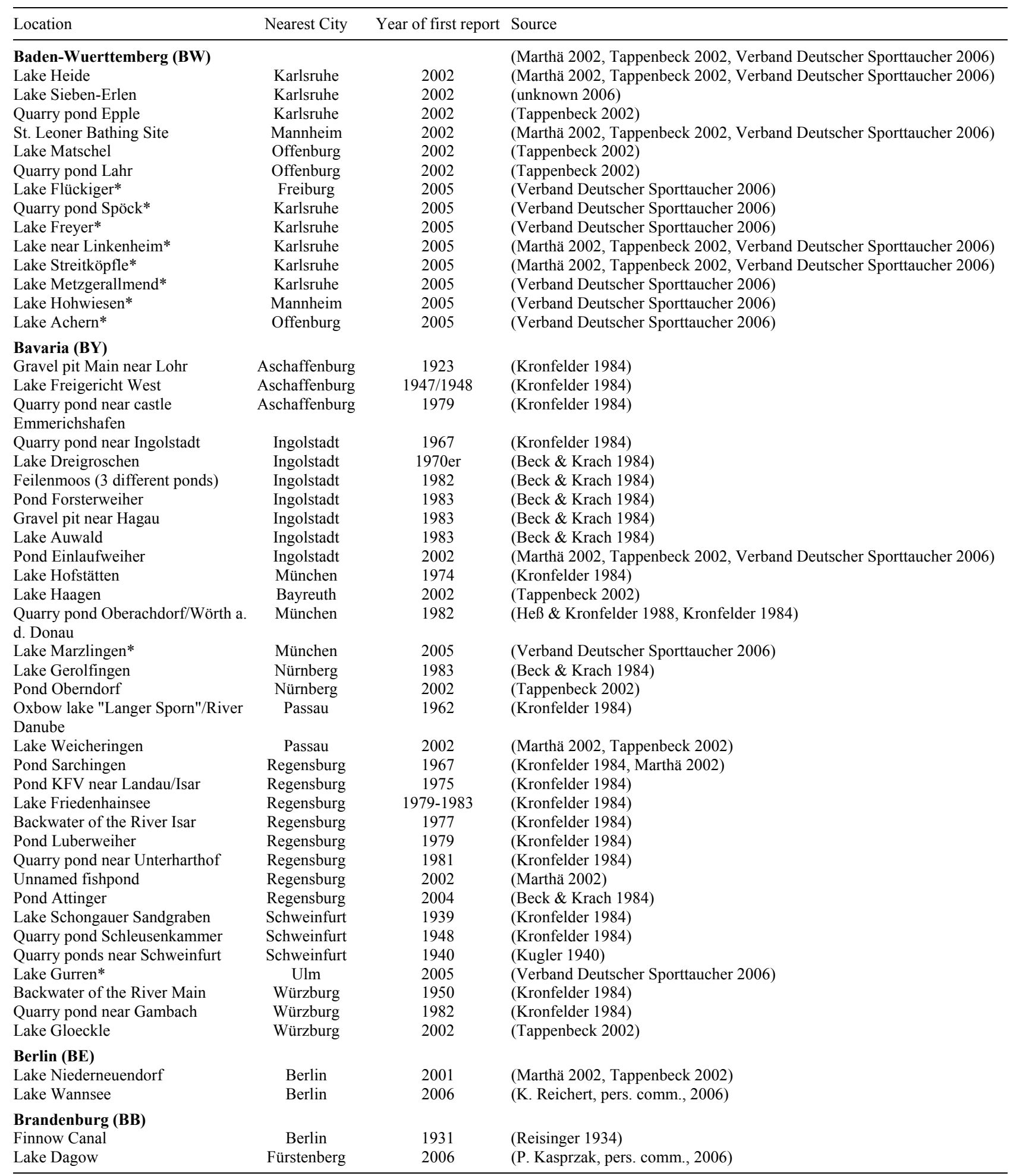


Tab. 1. Continuation.

\begin{tabular}{|c|c|c|c|}
\hline Location & Nearest City & Year of first report & Source \\
\hline \multicolumn{4}{|l|}{ Hesse (HE) } \\
\hline Aje & Darmstadt & 2002 & (Marthä 2002, Tappenbeck 2002, Verband Deutscher Sporttaucher 2006) \\
\hline Lake Westhafen, Frankfurt a. M. & Frankfurt a.M. & 1932 & (Reisinger 1934) \\
\hline Lake Krotzenburg & Frankfurt a.M. & 2002 & (Tappenbeck 2002) \\
\hline Lake Erlen & Frankfurt a.M. & 2002 & (Tappenbeck 2002) \\
\hline Lake Vogel & Frankfurt a.M. & 2005 & (Verband Deutscher Sporttaucher 2006) \\
\hline Lake Mönchswald* & Frankfurt a.M. & 2005 & (Marthä 2002, Verband Deutscher Sporttaucher 2006) \\
\hline Quarry pond Winkel* & Gießen & 2005 & (Verband Deutscher Sporttaucher 2006) \\
\hline \multicolumn{4}{|l|}{ North Rhine-Westphalia (NW) } \\
\hline Pond Alsdorf & Aachen & 1985 & (Jankowski 2000) \\
\hline Lake Rahmer & Duisburg & 2001 & (Verband Deutscher Sporttaucher 2006) \\
\hline Lake Alte Schachtanlage & Duisburg & 2002 & (Tappenbeck 2002) \\
\hline Lake Schleien & Duisburg & 2002 & (Tappenbeck 2002) \\
\hline Lake Wambach & Duisburg & 2003 & (BSWR (Biologische Station Westliches Ruhrgebiet) 2003-2006) \\
\hline Lake Töpper/Tegge & Duisburg & 2003 & (BSWR (Biologische Station Westliches Ruhrgebiet) 2003-2006) \\
\hline Rhein-Herne Canal & Duisburg & 2003 & (BSWR (Biologische Station Westliches Ruhrgebiet) 2003-2006) \\
\hline Lake Haubach & Duisburg & 2003 & (BSWR (Biologische Station Westliches Ruhrgebiet) 2003-2006) \\
\hline Landschaftspark Duisburg & Duisburg & 2004 & (BSWR (Biologische Station Westliches Ruhrgebiet) 2003-2006) \\
\hline Lake Goch Ness* & Duisburg & 2005 & (Verband Deutscher Sporttaucher 2006) \\
\hline Lake Loheide near the marina* & Duisburg & 2005 & (Verband Deutscher Sporttaucher 2006) \\
\hline Lake Zacharias & Dortmund & 2002 & (Tappenbeck 2002) \\
\hline Lake Möhne* & Dortmund & 2005 & (Verband Deutscher Sporttaucher 2006) \\
\hline Quarry pond Dornhecke & Düsseldorf & 1956 & (Dennert 1959) \\
\hline Lake Langenfeld & Düsseldorf & 2002 & (Marthä 2002, Tappenbeck 2002) \\
\hline Green Lake & Düsseldorf & 2003 & $\begin{array}{l}\text { (BSWR (Biologische Station Westliches Ruhrgebiet) 2003-2006, Verband } \\
\text { Deutscher Sporttaucher 2006) }\end{array}$ \\
\hline Lake Adolfo* & Düsseldorf & 2005 & (Tappenbeck 2002, Verband Deutscher Sporttaucher 2006) \\
\hline Lake Am Blankenwasser* & Düsseldorf & 2005 & (Verband Deutscher Sporttaucher 2006) \\
\hline Lake Elb* & Düsseldorf & 2005 & (Verband Deutscher Sporttaucher 2006) \\
\hline Lake Volksgartenweiher & Köln & 1931 & (Reisinger 1934) \\
\hline Lake Dornhecke & Köln & 1995 & (Verband Deutscher Sporttaucher 2006) \\
\hline Lake Stockemer* & Köln & 2002 & (Verband Deutscher Sporttaucher 2006) \\
\hline Lake Berggeist & Köln & 2004 & (Tappenbeck 2002, Verband Deutscher Sporttaucher 2006) \\
\hline Lake Fühlingen* & Köln & 2005 & (Verband Deutscher Sporttaucher 2006) \\
\hline Gravel pit Uckendorf* & Köln & 2005 & (Verband Deutscher Sporttaucher 2006) \\
\hline Garden pond & Münster & 2002 & (Tappenbeck 2002) \\
\hline \multicolumn{4}{|l|}{ Rhineland-Palatinate (RP) } \\
\hline Lake Dungkopf & Köln & 2003 & (Tappenbeck 2002, Verband Deutscher Sporttaucher 2006) \\
\hline \multicolumn{4}{|l|}{ Saxony (SN) } \\
\hline Gravel pitLeuben & Dresden & 2002 & (Tappenbeck 2002) \\
\hline Lake Vogelberg & Dresden & 2002 & (Marthä 2002, Tappenbeck 2002) \\
\hline \multicolumn{4}{|l|}{ Saxony-Anhalt (ST) } \\
\hline Quarry pond I, II und III, Löbejün & Halle (Saale) & 2002 & (Marthä 2002, Tappenbeck 2002, Verband Deutscher Sporttaucher 2006) \\
\hline Lake Wehrstädter & Magdeburg & 1994 & (Tappenbeck 2002) \\
\hline Lake Belicker & Magdeburg & 1997 & (Marthä 2002, Tappenbeck 2002) \\
\hline Lake Grüner Waldsee & Magdeburg & 2002 & (Marthä 2002, Tappenbeck 2002) \\
\hline Lido & Magdeburg & 2002 & (Marthä 2002) \\
\hline Lido Sandersdorf & Magdeburg & 2002 & (Marthä 2002, Tappenbeck 2002, Verband Deutscher Sporttaucher 2006) \\
\hline Süpplinger Canyon* & Magdeburg & 2002,2005 & (Marthä 2002, Verband Deutscher Sporttaucher 2006) \\
\hline Lake Förstergrube & Magdeburg & 2004 & (H. Preuss, pers. comm., 2006) \\
\hline \multicolumn{4}{|l|}{ Thuringia (TH) } \\
\hline Gravel pit & Erfurt & 2002 & (Marthä 2002) \\
\hline Lake Niederweimar* & Erfurt & 2003 & (Verband Deutscher Sporttaucher 2006) \\
\hline
\end{tabular}

\section{ACKNOWLEDGEMENTS}

We want to thank all the NEOBIOTA-participants of the NEOBIOTA project initiated by the German Underwater Federation (VDST). In addition, all the observations given by personal communication: Kerstin Reichert, Heike Preuss and Peter Kasprzak. The authors also want to thank Andrew Polaszek, Executive Secretary of the International Commission on Zoological Nomenclature, for his information on the correct spell- ing of C. sowerbii. This publication is dedicated to the late Mrs. Görtz, whose aquaristic interest provided us with the first polyps of $C$. sowerbii, which were then cultivated at the Department of Zoology, Universität Stuttgart, Germany.

\section{REFERENCES}

Acker, T.S. \& A.M. Muscat. 1976. Ecology of Craspedacusta sowerbii Lankester, a freshwater hydrozoan. Am. Midl. Nat., 95: 323-336. 
Ahmad, F.M., N.S. Sen, K.P. Mishra \& A.K. Bharti. 1987. A new species of Limnocnida (Limnomedusae, Coelenterata) from freshwater aquarium in India. Hydrobiologia, 144: 33-36.

Allen, J.A. 1910. Opinions rendered by the International Commission on Zoological Nomenclature. Science, 32: 380-382.

Allman, G.J. 1880. The freshwater medusa. Nature, 22: 218.

Augustin, H., W. Foissner \& H. Adam. 1987. A sewage plant as a remarkable new habitat of the fresh-water polyp Craspedacusta sowerbii (Hydrozoa: Coelenterata). Limnologica, 18: 225-226.

Beck, J. \& E. Krach. 1984. Bemerkungen zum Auftreten der Süßwasserqualle Craspedacusta sowerbii Lank. im mittelbayrischen Raum. Archaeopteryx, 1984: 41-50.

Beckett, D.C. \& E.J. Turanchik. 1980. Occurrence of the freshwater jellyfish Craspedacusta sowerbyi Lankester in the Ohio River. Ohio J. Sci., 32: 323-324.

Bouillon, J. \& F. Boero. 2000a. The hydrozoa: a new classification in the light of old knowledge. Thal. Sal., 24: 3-45.

Bouillon, J. \& F. Boero. 2000b. Synopsis of the families and genera of the hydromedusae of the world, with a list of the worldwide species. Thal. Sal., 24: 47-296.

Boulenger, C. \& L. Flower. 1928. The Regents Park medusa Craspedacusta sowerbyi and its identity with C. (Microhydra) ryderi. Proc. Zool. Soc. Lond., 66: 1005-1015.

BSWR (Biologische Station Westliches Ruhrgebiet). 20032006. Süßwassermedusen im westlichen Ruhrgebiet. http://www.bswr.de/Fauna/suesswasserqualle.htm. (Accessed: 14. Jun 2006)

Davis, C.C. 1955. Notes on the food of Craspedacusta sowerbii in Crystal Lake, Ravenna, Ohio. Ecology, 36: 364-366.

Deevey, E.S., Jr. \& J.L. Brooks. 1943. Craspedacusta in open water, Lake Quassapaug, Conneticut. Ecology, 24: 266-267.

Dejdar, E. 1934. Die Süßwassermeduse Craspedacusta sowerbii Lankester in monographischer Darstellung. $Z$. Morphol. Ökol. Tiere, 28: 595-691.

Dennert, G. 1959. Ein interessantes Hohltier unserer heimischen Süßwasserfauna: Craspedacusta sowerbii Lank. Mikrokosmos, 48: 79-83.

Dexter, R.W., T.C. Surrarrer \& C.W. Davis. 1949. Some recent records of the freshwater jellyfish Craspedacusta sowerbyi from Ohio and Pennsylvania. Ohio J. Sci., 49: 235-241.

Fantham, H.B. \& A. Porter. 1938. Occurrence of the freshwater medusa Craspedacusta sowerbii in eastern Canada. Nature, 141: 515-516.

Heß, W. \& M. Kronfelder. 1988. Zur Nahrungsaufnahme der Süßwassermeduse Craspedacusta sowerbii Lankester. Acta Albertina Ratisbonensia, 45: 243-248.

Jankowski, T. 2000. Chemical composition and biomass parameters of a population of Craspedacusta sowerbii Lank 1880 (Cnidaria:Limnomedusa). J. Plankton Res., 22: $1329-1340$.

Kramp, P.L. 1950. Freshwater medusae in China. Proc. Zool. Soc. Lond., 120: 165-184.

Kronfelder, M. 1984. Notiz zum Vorkommen der Süßwassermeduse Craspedacusta sowerbii Lankester in Bayern. Spixiana Muenchn, 7: 1-3.

Kugler, H. 1940. Neuer Fundort von Craspedacusta sowerbii Lankester. Zool. Anz., 130: 250.

Lankester, E.R. 1880a. On a new Jellyfish of the Order Trachomedusae, living in fresh water. Science, 1: 34.
Lankester, E.R. 1880b. On Limnocodium (Craspedacusta) sowerbii, a new Trachomedusa inhabiting freshwater. $Q$. J. Microsc. Sci., 20: 351-371.

Lundberg, S. \& J.-E. Svensson. 2003. Medusae invasions in Swedish lakes. Fauna Och Flora, 98: 18-28.

Marthä, H. 2002. Süßwasserquallen (Craspedacusta sowerbii). http://www.taucher.net/redaktion/22/Suesswasserquallen Craspedacusta_sowerbii 6.html. (Accessed: 14. June 2006).

Moser, J. 1930. Microhydra E. Potts. Sitzungsber. Ges. Naturf. Freunde., Berlin.

Payne, F. 1924. A study of the fresh-water medusa, Craspedacusta ryderi. J. Morph., 38: 387-430.

Pennak, R.W. 1956. The fresh-water jellyfish Craspedacusta in Colorado with some remarks on its ecology and morphological degenerataion. T. Am. Microsc. Soc., 75: 324331.

Persch, H. 1933. Untersuchungen über Microhydra germanica Roch. Z. Wiss. Zool., 144: 163-210.

Petrusek, A., J. Šedivy, S. Lundberg \& J.-E. Svensson. 2005. Detecting multiple invasions of Craspedacusta sowerbyi by indentification of the sex of the medusae. INWAT: Biological invasions in inland waters, Firenze, May 5-7, 2005

Potts, E. 1897. A North American fresh water jelly fish. Am. Nat., 31: 1032-1035.

Purcell, J.E. 2005. Climate effects on formation of jellyfish and ctenophore blooms: a review. J. Mar. Biol. Assoc. U.K., 85: 461-476.

Rayner, N.A. 1988. First record of Craspedacusta sowerbyi Lankester (Cnidaria: Limnomedusae) from Africa. Hydrobiologia, 162: 73-77.

Rayner, N.A. \& C. C. Appleton. 1992. Craspedacusta sowerbii, new record (Cnidaria: Limnomedusae) from southern Africa. S. Afr. J. Zool., 27: 143-145.

Reisinger, E. 1934. Die Süßwassermeduse Craspedacusta sowerbii Lankester und ihr Vorkommen im Flußgebiet von Rhein und Maas. Die Natur am Niederrhein, 10: 33-43.

Reisinger, E. 1957. Zur Entwicklungsgeschichte und Entwicklungsmechanik von Craspedacusta (Hydrozoa, Limnotrachylina). Z. Morphol. Ökol. Tiere, 45: 656-698.

Roch, F. 1924a. Microhydra germanica - die deutsche Süßwassermeduse. Bl.f. Aquar. Terr. Kde., 36: 205-208.

Roch, F. 1924b. Microhydra germanica, eine neue Süßwassermeduse. Zool. Anz., 58: 131-136.

Schmitt, W.L. 1939. Freshwater jellyfish records since 1932. Am. Nat., 73: 83-89.

Stiles, C.W. 1910. Summaries of six opinions $(9,11,13,15$, $17,18)$ by the International Commission on Zoological Nomenclature. Science, 31: 150-151.

Tappenbeck, L. 2002. Die Süßwasserqualle (Craspedacusta sowerbyi, Lankester 1880). http://www.halophila. de/startseite /startseite.html. (Accessed: 14. June 2006).

Tattersall, W.M. 1933. Occurrence of Craspedacusta sowerbyi Lankester in Monmouthshire. Nature, 132: 570.

Thomas, I.M. 1951. Craspedacusta sowerbii in south Australia, with some notes on its habits. T. Roy. Soc. South Aust., 74: 59-65.

Unknown. 2006. Tauchreviere. http://www.staempfli.de /Tauchen /tauchen .html. (Accessed: 19.Sept.2006).

Verband Deutscher Sporttaucher, e.V. 2006. NEOBIOTA neue Arten in Tauchgewässer. http://www.neobiota.info. (Accessed: 31. Aug. 2006). 